\section{Gategory}

Metal-Catalyzed Asymmetric Synthesis and Stereoselective Reactions

\section{Key words}

\section{copper}

desymmetrization

kinetic resolution

\title{
Consecutive Intramolecular
}

\section{Desymmetrization and Kinetic Resolution}

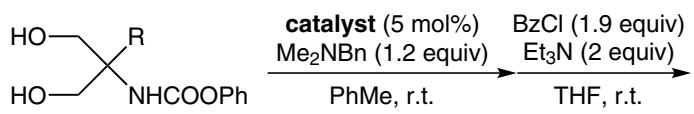<smiles>O=C1NC(P)(COC(=O)c2ccccc2)CO1</smiles>

Selected examples:<smiles>O=C1NC(Cc2ccccc2)(Cc2ccccc2)CO1</smiles><smiles>CCCC1(COC(=O)c2ccccc2)COC(=O)N1</smiles><smiles>C=CC[C@]1(COC(=O)OCc2ccccc2)COC(=O)N1</smiles>

$85 \%$ yield $97 \%$ ee
$74 \%$ yield

$98 \%$ ee<smiles>CCCCOCC[C@@]1(c2ccccc2)COC(=O)N1</smiles>

$87 \%$ yield

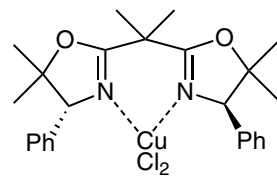

catalyst

Proposed intermediates in desymmetrization and kinetic resolution:

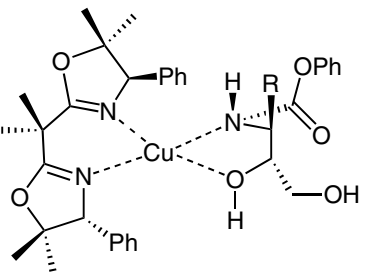
desymmetrization<smiles>O=C1NC(P)(CO)CO1</smiles>

kinetic resolution<smiles>[2H]C[C@]1(COC(=O)c2ccccc2)COC(=O)N1</smiles><smiles>Cc1ccc([C@]2(COC(C)(C)C)COC(=O)N2)cc1</smiles>

$80 \%$ yield
Significance: This paper describes the consecutive intramolecular desymmetrization and kinetic resolution of 2-substituted $\mathrm{N}$-phenoxycarbonylserinols by using bisoxazoline- $\mathrm{CuCl}_{2}$. The reaction products are obtained in good yield and excellent enantioselectivities (94-99\% ee).

SYNFACTS Contributors: Hisashi Yamamoto, Atsuto Izumiseki Synfacts 2014, 10(1), 0048 Published online: 13.12.2013 DOI: 10.1055/s-0033-1340432; Reg-No.: H15313SF
Comment: The authors developed a unique asymmetric catalysis system using a single chiral Lewis acid catalyst, which steers two consecutive asymmetric reactions of intramolecular desymmetrization and kinetic resolution. The two successive chemical conversions became unusually enantioselective, resulting in the production of the oxazolidinone benzoates with excellent enantioselectivities, which signifies a powerful and synergistic dual function catalyst effect by a chiral catalyst. 